\title{
Dagens kroppsidealisering og kristen kroppsrealisme
}

\author{
Av Ove Olsen SÆLE
}

\section{ABSTRACT}

Our approach to the human body has always correlated with the contemporary cultural context. Today's modern hi-tech society, with its extreme body discipline and body idealism, seems to express an even stronger mind-body duality than ever. The historical concept of mind-body duality, where the human flesh was subordinated and suppressed by human consciousness, soul and spirit, seems to form an underlying basis for today's superficial body approach as well. Christian theology, paradoxically, can also provide a more subtle, positive and comprehensive conception of the body, which hopefully can function as a counterbalance to the current superficial body approach.

Keywords: Mind-body duality - Ireneus, Descartes • today's superficial body approach • a Christian conception of body

\section{Ove OlSEN SÆLE, Født: 27.11.1963, 1.lektor i kroppsøving og lektor i kristendom (cand. philol.) NLA Høgskolen, avdeling Bergen, Amalie Skrams vei 3, Boks 74 Sandviken, 5812 Bergen, e-post: Ove.Saele@nla.no}

\section{INTRO}

Å hevde at en kristen kroppsforståelse kan utgjøre en konstruktiv og positiv stemme til det flere hevder utgjør en kroppsfokusert og kroppsidealisert samtidskultur, kan gjerne oppfattes som både provoserende og problematisk. Det skyldes det faktum at kroppen gjennom historien har hatt dårlige kår innenfor kirke og kristenliv. Jeg vil likevel hevde, gjennom kommende drøftelse, at kristendommen og Bibelen fremmer et positivt og realistisk danningsperspektiv på kroppen, som del av en helhetlig og positiv kristen antropologi, som kan fungere som en viktig og sunn korreks til dagens kroppsdyrkelse. Begrepet som er brukt i tittelen, kristen kroppsrealisme, er ikke noe vitenskapsteoretisk konsept, men er uttrykk for en dannings- orientert og helhetlig kroppsorientering, slik den fremstår innenfor en kroppsfenomenlogisk og bibelsk forståelseshorisont. Dette er en posisjon som i drøftelsen blir kontrastert opp mot det jeg har kalt «dagens kroppsidealisering», som uttrykk for det jeg mener utgjør vår tids dyrkelse av idealkroppen, slik den kommer til uttrykk i vårt moderne samfunn.

\section{TRADISJONELL VESTLIG KROPPS- OG IDRETTSKULTUR - ET DANNELSESPROSJEKT}

Både den alminnelige og idrettsutøverens kropps- og bevegelseskultur i den vestlige historie inngår som en del av en større dannelsesprosess. Vår lange idretts- og kroppsøvingsfaglige historie kan bevitne at kropp og 
idrettsutøvelse er blitt dyrket og tolket innenfor så vel et guddommelig som et moralsk og helsemessig paradigme. Vestlig idrettshistorie har sine røtter i den antikke olympismen, der kroppskulturen hadde nære forbindelser til den greske gudsdyrkelsen og samfunnets utdanningssystem (Se eksempelvis Dombrowski 2009; Guttmann 1978). Vår egen norrøne idrettstradisjon kan også vitne om en lignende kroppskultur (Goksøyr 2008). Også den moderne idretten, slik den vokser frem i England på 1850-tallet, har klare forbindelser til det engelske utdanningssystemet, der idrett og kropp ble sett på som et større dannelsesprosjekt, knyttet til sosialetiske, helsemessige og militære formål (Hyland 1990).

Også norsk skole, gjennom kroppsøvingsfaget og fysisk aktivitet (Zoglowek, 2006), og barnehagen, gjennom sin lek (Sæle, 2012, 2013), er læringsarenaer som er kjent for å fremme et bredt danningsperspektiv på kropp og bevegelse. Og vi kan legge til dagens organiserte idrett, som har flere og allsidige danningsmål knyttet til sin idrettsvirksomhet (NIF 2011). En sentral debatt som pågår, er hvorvidt dagens kroppsøvingsfag og organisert idrett fremmer kroppsbevegelse ut fra sin egenverdi (autonomi), eller om denne virksomheten oppfattes som middel for noe annet. Er det slik at dagens kropps- og bevegelseskultur, enten denne foregår i regi av skolen, idretten eller på frivillig basis, baserer seg på grunnverdier som bevegelsesglede, velvære, vennskap etc., eller driver man slik virksomhet ut fra nytteverdien å «se bra ut»? Er det slik at dagens samfunn legger sterke føringer på den enkelte om å dyrke og «bygge» idealkroppen?

\section{DAGENS SITUASJON}

Mennesket synes å alltid ha vært opptatt av kroppsutseende, noe som kan bekreftes gjennom ulike kulturer i historien der mennesket har endret på kroppsutseende gjennom kjønnsrelaterte og kroppsmodifiserende tiltak (Morris 1998). Den individuelle kroppen har likevel aldri tidligere i historien vært en så sentral sosial identitetsmarkør som i vår tid, en kropp som er blitt overlatt til den enkelte selvå danne (Giddens 1997). Kroppsidentitet er knyttet til sosial status, og kroppsutseendet fungerer for mange som en indikator på vellykkethet (Breivik 2013:212). I en tid der man er overlatt til seg selv med å realisere sitt kroppsdanningsprosjekt, er det også mange som bærer på negative tanker om kroppen sin. En helseundersøkelse fra Akershus viste at det bare var 25 prosent jenter og 55 prosent gutter på videregående som likte kroppen sin (Rødje m.fl. 2004). Tendensen var større kroppsmisnøye jo eldre man ble, noe også andre studier bekrefter. ${ }^{1}$ At mange er misfornøyd med kroppen sin, kan skyldes at de nettopp setter strenge krav til hvordan de skal se ut (Breivik 2013:212). At mange sliter med dårlig kroppsbilde, har også sammenheng med at en del sliter med overvekt. Det er påvist at de som driver lite med fysisk aktivitet, også er blant dem som er mest misfornøyd med sitt kroppsutseende (Breivik 2013).

Breivik poengterer at det å gå ned i vekt, utvikle muskelmasse og ha en godt trent kropp, både gir helsemessige gevinster og er med på å styrke ens kroppsbilde. Men det er et faktum at også enkelte toppidrettsutøvere (med atletiske kropper) sliter med kroppsrelaterte forstyrrelser (såkalt kroppsdysmorfi),

\footnotetext{
1 Jf. den internasjonale studien «Helsevaner blant skoleelever» (HBSC, 2005/06) som viste at hele 50 prosent av norske 15-årige jenter anså seg som tykke, og 23 prosent av guttene, tall som korresponderte med de nordiske landene. Og Norsk monitor (2001-2013) viser at bare 7,6 prosent av den voksne befolkning var meget fornøyd med kroppen sin.
} 
som følge av kroppslige krav idretten selv setter (Sundgot-Borgen m.fl. 2004). ${ }^{2}$ Det pekes på årsaker som at jenter er utsatt for biologiske endringer kombinert med strenge samfunnskrav om å inneha idealkroppen. I tillegg til kjente spiseforstyrrelser som anoreksi, og for gutter og menn, såkalt megareksi, er det også stadig flere jenter som utvikler såkalt ortorek$s i{ }^{3}$ Det kvinnelige kroppsidealet synes også å dreie mot en hardere og mer maskulin kropp, jf. uttrykket «strong is the new skinny».

Men man trenger ikke være eliteutøver for å være opptatt av kropp. Stadig flere driver i dag med systematisk trening, og de gjør det gjerne fordi idrettsprestasjoner i mosjonskonkurranser eller det å «se bra ut», gir sosial status. Ikke bare den moderne kroppen, men også den moderne idretten synes å være et individuelt danningsprosjekt. Stadig flere velger alternative treningsformer til de tradisjonelle som NIF tilbyr. Fitnessbransjen og trening på treningsstudio er en sterkt ekspanderende idrettskultur i dag. Breivik skriver (Breivik 2013:97): «De kommersielle treningssentrene representerer ved siden av det sterkt urbane en kombinasjon av det narsissistiske og den rasjonelle disiplin. Både Giddens' teori om selvkonstruksjon og Laschs teori om den moderne narsissistiske kultur kan bidra til forståelsen». En ny tendens er med andre ord at stadig flere trener for å realisere en «fit» kropp, ikke for å prestere på idrettsarenaen. Christofer Lasch (1978) hevder at den moderne toppidretten, slik den kommer til uttrykk i USA, er i likhet med kroppen blitt en ren sekulær og triviell underholdningsvirksomhet. I takt med kroppens sekularisering har også idretten mistet sin fortidige, religiøse forbindelse (ibid.:106f.).

Både unge og voksne utsettes i dag for et ekstremt kroppspress fra sosiale medier. Veldreide kroppsformer møter oss ikke bare på idrettsarenaen og på catwalken, vi møter dem også innenfor musikkbransjen, forretningslivet og hos nyhetsopplesere og værmeldere på TV-skjermen. Det moderne menneske blir utsatt for et enormt kroppsmedia-press som stort sett formidler budskapet om evig ungdom, seksualitet og vitalitet. Loland (2003:5) viser til Anthony Synnott (1993) som taler om kroppen som et av imageindustriens viktigste angrepspunkt, fordi det er her våre drifter, begjær og lystfølelser sitter. Vi kan her legge til de mange (kvinnelige) ukeblader som tematiserer kropp, kosthold, og utallige slankemetoder. Det er heller ikke uvanlig at kjente idrettsutøvere til tider viser seg naken i reklame, noe Von der Lippe (2011) mener er eksempel på at dagens idrettsutøvere har mistet sin tradisjonelle funksjon som moralske rollemodeller, og står igjen som «bare» kroppsmodeller. Mediesamfunnet formidler med andre ord ofte et idealisert kroppsbilde som mange ønsker å oppnå, men som de færreste er i stand til å realisere. Dette er en fremstilling av kropp som objekt, fjernt fra slik mange erfarer sin subjektive, opplevde kropp. Med en slik form for misnøyens logikk, der den enkelte måler sin subjektive kroppserfaring opp mot den idealiserte media-kroppen, vil majoriteten oppleve at den subjektive kroppen alltid vil komme til kort overfor den idealiserte. Det vil med andre ord fortone seg for

2 De refererer blant annet til en studie fra 2010 der 42 prosent av kvinnelige eliteutøvere innenfor estetiske idretter hadde spiseforstyrrelser. Også blant vektklasse-idretter/kampidretter, utholdenhetsidretter, ballidretten, og der «slank kropp» er fordelaktig, som i skihopp og fitness.

3 Begrepet "Anoreksi", av gresk a - "u-, ikke” og "orexis", appetitt, dvs. manglende appetitt/begjer (Caprona 2013:1420). "Megareksi», kommer av gresk «mega»- «stor», og uttrykker stor appetitt/begjer, mens «ortoreksi» kommer fra det gresk «orth»«korrekt», altså korrekt appetitt/begjer, jf. Sæle 2014:187. 
de fleste som en evigvarende jakt etter den illusoriske kroppen.

\section{Den sekulariserte kroppen}

Det finnes i dag også andre former for kroppsmodifiserende tiltak enn trening. Tidligere nevnte Anthony Giddens (1997:119) hevder at vi i dag står overfor en omfattende kroppsindustri der stadig flere foretar plastiske inngrep. Det er slik at det meste i menneskekroppen i dag er utskiftbart, en kropp han kaller modulcer, i betydningen formbar. Dette er, ifølge ham, uttrykk for en gjennomkommersialisert kropp som trues av identitetskrise fordi når den utsettes for «plastiske inngrep $\gg$, står den i fare for å miste sin referanse til sitt eget genetiske selv. Det er likevel slik at nordmenn flest er fortsatt skeptisk til å modifisere sin kropp ved hjelp av ulike tekniske inngrep, med unntak av mindre «inngrep $\gg$ som tatovering og fettsuging (Breivik 20013:208).

Utviklingen av en slik modulær, selvskapt kropp, er uttrykk for at vi forholder oss til kropp som en sekulær størrelse. Det kan virke som vår tids sterke kroppsdisiplin (les: trening) speiler et sekulært kroppsforhold, der tidligere religiøse kroppsritualer uteblir og erstattes av nye. Dette er i tråd med den polske sosiologen Zygmunt Bauman (2001) sin mening, som kaller vår tids kroppsidentitet en flytende modernitet, som er blitt privatisert og avsakralisert. Sosiologen Giddens bekrefter en slik moderne kroppsforståelse og taler om det moderne samfunnet som: $\ll .$. et kolossalt sirkus som består av folk som sprenger grenser i alle retninger - som skifter identitet, utseende, kjønn, sosiale roller, selv bevissthet på en måte som de fleste folk tidligere ville trodd var umulig» (1997:71). Giddens hovedanliggende er at menneskets identitet, også på kroppens område, skapes i møte med modernitetens raske skiftninger, noe som har ført til at stabile, tradisjonelle identitetsmarkører er blitt erstattet av mer relative og dynamiske sosiale identitetsmarkører. Han hevder at det er minst tre forhold som konstituerer det moderne samfunnet. Det skjer en stadig $ø$ kende grad av fysisk mobilitet, i tillegg til en symbolsk mobilitet hvor ord og visuelle forestillinger svirrer rundt i verden som aldri før, transportert av radio, $\mathrm{TV}$, telefon og vårt nye cyberspace. Og han taler om våre raske kulturelle endringer hvor man stadig skifter livsstil, verdier og forestillinger.

Også psykiateren Finn Skårderud (1991) tar opp denne tematikken; en kropp som har mistet sin «ytre» trosreferanse og i stedet dyrker seg selv. På denne måten har kroppen, ironisk nok, selv inntatt en religiøs posisjon. Gud som skaper og opprettholder av menneskekroppen blir anakronisme. Med oppløsning av de tradisjonelle tegnene er ikke identitet lenger noe som er gitt, den må skapes, og menneskene søker identiteten i kroppsoverflaten, hevder han. Den moderne kroppen er fylt opp av symbolske tegn løsrevet fra sin naturlige og guddommelige preferanse.

\section{Kroppen som display}

Som uttrykk for vår kropp/sjel-dualistiske arv, forholder mennesket seg til kroppen på en objektiv, instrumentell måte. Å betrakte den som en ting, som noe mennesket har, kan synes å bli bekreftet i vår tids opptatthet av kroppen som display. Den franske filosof og samfunnskritiker Jean Baudrillard beskriver at forbrukersamfunnets verdier har kolonisert den faktisk kroppslige livsverden, noe som har ført til at mennesket forholder seg til kroppen fremst av alt som en overflatisk størrelse. Han hevder kroppen er blitt redusert til et blend- 
verk, et skinn av virkeligheten, ${ }^{4}$ og taler om vår nye kroppslige hyperrealitet, der kroppen er blitt «oppslukt» av media. I seinere bøker viser han til filmen The Truman Show (1998), som illustrerer dette. Her møter vi funksjonæren Truman som gradvis oppdager at han spiller hovedrollen i et 24-timers direkteoverført tv-show. Hele hans verden består av falske kulisser uten noen substans, alt er en illusjon, et skinnbedrag. Til slutt kommer han seg ut av denne manipulerte verden, gjennom en dør, ut i den faktiske verden. ${ }^{5}$

I The Consumer Society: Myths and Structures (1998) hevder han at kroppen i dag har overtatt sjelens plass, det som har vært sjelens dominante rolle gjennom den vestlige historie, men kroppens status er ikke lenger knyttet til noen guddommelig eller sjelelig moralsk frelse. Dermed står det postmoderne mennesket tilbake med en kroppskultur uten sjel og ånd, som næres av narsissistiske og hedonistiske ideer, og som drives frem av en manipulerende, effektiv og kynisk logikk, som følger medie- og forbrukersamfunnets lover (ibid.:129):

In the consumer package, there is one object finer, more precious and more dazzling than any other - and even more laden with connotations than the automobile, in spite of the fact that that encapsulates them all. That object is the BODY. Its 'rediscovery', in a spirit of physical and sexual liberation, after a millennial age of puritanism ... and the sacrificial practices attaching to it all bear witness to the fact that the body has today become an object of salvation. It has literally taken over that moral and ideological function from the soul.
Baudrillard, som selv kalte seg transmodernist, var påvirket av medieviteren Marshall McLuan som på 1960-tallet gjorde seg bemerket med sin frykt for det nye TV-apparatet, som innvarslet et nytt og skremmende skjermsamfunn, der han mente at den sanselige kroppen ville tape terreng. Hans kjente tese «The medium is the message» poengterer at mediet selv er med på å forme budskapet. ${ }^{6}$ Den seinere McLuan (1997) søker å bekrefte sine profetier ved å hevde at dagens digitale verden er blitt en forlengelse av kroppen, våre elektriske forlengere. Med det mener han at gjennom vår bruk av virtuell kommunikasjon, der vi kan kommunisere på tvers av kloden, fører det til en bevissthetsforlengelse der mediet transporterer våre tanker, og på den måten skaper mennesket en «discarnate man», en kroppsløs skapning av rendyrket ånd.

\section{Den disiplinerte kroppen}

Det er også de som hevder, i forlengelsen av forestillingen om kroppen som objekt, at den moderne kroppen er underlagt ulike former for kroppsdisiplinering. Ifølge filosofen Michel Foucault (1997) vil menneskekroppen i enhver kulturell kontekst være underlagt en form for kontroll og disiplin. Han har sett nærmere på det 18. århundre, som han mener introduserer dagens strenge kroppsdisiplin. I overgangen til den moderne tid ble kroppsdisiplineringen et allment fenomen og ikke lenger forbeholdt enkelte samfunnsgrupper, hevder han. Selv om han nevner klosterlivets kroppsrutiner som en viktig kilde til den nye kroppsdisiplinen, ser han likevel på denne som annerledes enn den moderne, fordi den

\footnotetext{
4 Her innfører han det latinske begrepet «simulacrum», som kan oversettes med «blendverk», se nærmere Baudrillard (1994).

5 For en nærmere drøftelse av Baudrillards kroppssyn, i forhold til en kristen posisjon, se Sæle (2014).

6 Se også Neil Postman (2004).
} 
var motivert ut fra høyere religiøse mål, mens modernitetens kroppsdisiplin er tuftet på pragmatiske insentiver.

Inevnte boktilSkårderud, Sultekunstnerne: kultur, kropp og kontroll (1991), viser han hvordan kroppsdisiplinen har kommet til uttrykk i historien. Han deler Foucault sitt syn og hevder at det moderne mennesket lever i en slags anorektisk tidsalder hvor man søker det absolutt rene ved å tilintetgjøre seg selv. Bokens tittel refererer til Kafka sin novelle «Sultekunstneren», som illustrerer vår moderne tidsånd $\mathrm{og}$ identitet, der selvet tømmes for substans fordi det jager etter en illusorisk renhet, perfeksjon og disiplin. I Uro (1998) behandler han tematikken næermere i sitt møte med sine pasienter.

Når dagens idrettsutøvere er underlagt troen på den moderne idrettens rasjonelle logikk som forteller at man alltid kan prestere sterkere, hoyere, fortere («citius, altuis, fortius »), står man også i fare for å presse kroppen til det uforsvarlige (Tangen 2003). Den ekstreme kroppsdisiplin som en del idrettsutøvere i dag utsetter seg for, kan delvis minne om det samme mønsteret som den spiseforstyrrede kroppen er underlagt, der man stiller svært strenge krav til diett, hygiene etc., tiltak der man forholder seg til kroppen som objekt. Et annet utslag av en ekstrem kroppsdisiplin er det som i dag kalles for tvangstrening eller treningsmisbruk («exercise addiction/ abuse»), der særlig menn er psykisk og fysisk avhengig av å trene så mye at det går ut over egen helse og livet ellers. En mildere form for denne besettelsen er det man i Norge gjerne betegner som Birkebeiner-syndromet, der stort sett voksne menn deltar i utallige mosjonsløp (Martinsen 2011).

Også i religiøse settinger har kroppsdisiplinerende tiltak vært vanlig praksis, noe vår lange idrettshistorie tydelig bevitner
(Guttmann 1978). Da den moderne idretten vokste frem i England midt på 1850-tallet, var det også religiøse miljøer, som Muscular Christianity, som fremmet idrett blant ungdommen og som så på dette som et kroppsdisiplinerende, moralsk danningsprosjekt (Ladd \& Matthisen 1999; Clifford 2001). Korsgaard (1986) peker også på den tidligere protestantismens etiske dydsidealer (arbeidsdisiplin, flid, rasjonell livsførsel og askese), som en mentalitet som ble en forutsetning for den moderne idrettens utvikling i protestantiske land. Han baserer sin teori på sosiologen Max Weber (1973), som hevdet at den protestantiske tenkning ble en forutsetning for industrialiseringens framvekst, og dernest for framveksten av den moderne idrett. Arbeidet ble sett på som et hellig kall, og suksess $\mathrm{i}$ arbeidslivet ble et bevis på Guds velsignelse. Henning Eichberg (1986) kan også vise til tidlige katolske miljøer som har fremmet en idrettsasketisk praksis.

\section{Vestens kropp/sjel-dualisme - kropp som objekt}

Hvorfor er det blitt slik? En avgjørende premissleverandør for dagens opprettholdelse av skillet mellom en idealistisk og realistisk kroppsfremstilling, er den vestlige antropologiske dualisme der menneskets soma opp gjennom den vestlige historie er blitt undertrykt til fordel for menneskets psyke, sjel eller ånd (Spicker 1970). Kroppens vestlige historie omhandler en slik asymmetri mellom menneskets kropp og psyke (Sæle 2010). Når det tales om et dualistisk menneskesyn, er dette en arv som på ingen måte utgjør noen enhetlig størrelse. Det er likevel tre tradisjoner som ofte nevnes som hovedkilder til en slik forestilling: den antikke, oldkirkelige og kartesianske tradisjon. Disse nevnes under som eksempler hentet fra ulike perioder, som 
bevitner hovedtrekk som drøftelsen ønsker å forankre seg i.

Juvenals motto «mens sana in corpore sano» - «en sunn sjel i et sunt legeme» gir uttrykk for grekernes helhetlige syn på mennesket og kroppen. Mennesket stod i antikken i nær relasjon til sin omkringliggende natur, sin gud og sitt fellesskap. Slik inngikk hele mennesket, både dets kropp og sjel, i et integrert hele med kosmos. Kroppen ble oppfattet som et mikrokosmos i det store makrokosmos. Symbiosen mellom kropp og sjel kom klart til uttrykk innenfor den antikke idretten, med atletens kroppssymmetri som viste til en tilsvarende kropp-sjel symmetri, med kroppens lidenskaper som spilte på lag med sjelens kvaliteter (Dombrowski 2009; Miller 2004; Reid 2011). Men etter hvert som den greske filosofien vokser frem, nedvurderes menneskekroppen til fordel for mennesketanken - et kroppssyn som kan ledes tilbake til Platons (427-348 f.Kr) idélære. Det er selve ideene, tankene og begrepene forut for, og bak, den konkrete tingen og handlingen som uttrykker sannheten, og mennesket er i besittelse av å gripe denne gjennom sin evige sjel, bevissthet. Han tematiserer sin kroppsdualisme blant annet i dialogene Faidros, Timaios, Symposiet og Staten, hvor Sokrates er hans talerør. I hans dialog Faidros kan vi lese om Sokrates som i samtale med sin venn Simmias argumenterer for at filosofi er øvelse i å dø fra sin kropp (Platon 2001:25f). Platon sin favorisering av menneskets tenkning skyldes hans forestilling om kroppen som noe dennesidig og forgjengelig, mens sjelen gav han evig status.

Eksempler på et dualistisk menneskesyn finnes også innenfor den teologiske tradisjon, med samme begrunnelse som hos Platon. De fremste eksempler på en slik tenkning finnes hos de gnostiske kirkefedrene. I oldtiden fan- tes det kristne tenkere som også forfektet et nyansert og helhetlig kropp-sjel-syn, eksempelvis Ireneus, jf. neste avsnitt. Det var særlig datidens gnostisisme og dens ulike retninger som fremmet en hierarkisk, dualistisk antropologi (Leder 1990; Turner 2008). Augustin (354 - 430 e.Kr.) kan også nevnes, som har et svært nyansert bilde av menneskekroppen. I sin biografi, Bekjennelser (1961), fremstiller han kroppen på en gjennomført negativ måte, en fremstilling som må leses i lys av at han beskriver nærmere sitt oppgjør med sin manikeiske og nyplatonske fortid. I verket skriver han om det indre mennesket, og sikter til en høyere, åndelig ekstatisk opplevelse i møte med guddommen. Han er tydelig på at kroppen i utgangspunktet er en positiv, gudgitt størrelse, men denne forestillingen overskygges av hans beskrivelse av, og oppgjør med, kroppens falne og forgjengelige natur (Sæle 2010:63ff.).

Kroppsdualismen fikk ny aktualitet ved inngangen til vår moderne tid, med René Descartes (1596 - 1650 e.Kr.) sin antropologiske dualisme der han foretar et radikalt skille mellom menneskets tenkende del («res cogitans») og dets fysiske, utstrakte del («res exentia») (Descartes 1992:6,9):

Og siden jeg kanskje (eller sikkert, som jeg snart skulle si) har en kropp som jeg er nøye forbundet med, og fordi at jeg ikke desto mindre, på den ene side, har en klar og tydelig forestilling om meg selv som noe tenkende og ikke utstrakt, og jeg på den annen side har en tydelig forestilling om kroppen som noe utstrakt, ikke-tenkende, er så meget sikkert at jeg er forskjellig fra min kropp, og at jeg kan eksistere uten den.

Slik innleder han den moderne mekaniske dualisme hvor menneskets rasjonale blir overordnet dets legemlige utstrekning. Hans 
hovedtese «cogito, ergo sum» - «jeg tenker, altså er jeg»- formidler menneskets rasjonale som sentrum for erkjennelsen, en tese han kom frem til på bakgrunn av et rasjonelt forsøk på å bevise Guds fullkomne eksistens (Sæle 2010:122f). I forlengelse av sin antropologiske dualisme betraktet han menneskekroppen som en maskinell størrelse, et kroppssyn som forsterket forestillingen om kroppen som noe tingliggjort. At menneskets rasjonale blir stående som eneste sannhetskriterium, sammen med hans logiske matematiske metode, kan brukes til inntekt for både et rasjonalistisk, positivistisk og sekularisert kroppssyn. Hans tenkning ble slik også en direkte forutsetning for utviklingen av den moderne medisin, og dertil den moderne idrettsforskning (anatomi, fysiologi, biomekanikk og treningslære) i etterkrigstid (Loland 2003). Det kartesianske paradigme skulle med andre ord vise seg å bli mønsterdannende for forestillingen om den effektive og prestasjonsorienterte idrettskroppen.

ET KRISTENT, FENOMENOLOGISK KROPPSKONSEPT SOM MOTVEKT

TIL DAGENS OVERFLADISKE KROPPSSYN

\section{Den nyreligiøse kroppsdyrking}

Flere av dagens moderne tenkere ønsker å ta et oppgjør med sin dualistiske fortid ved å vise til kroppen som en subjektiv opplevd størrelse. Kanskje den fremste systematiske bidragsyter til en slik kroppsfilosofi er den franske filosofen Maurice Merleau-Ponty (1994). Hans helhetlige kroppsforestilling ligner den hebraiske, men med sitt fenomenologiske utgangspunkt utelukker han en kristen dualistisk ontologi (skillet mellom immanens og transcendens). Han står for en kroppsfenomenologi som hevder at mennes- kets tenkning alltid vil være uløselig knyttet til kroppens persepsjon og erfaring. Menneskets sanseerfaring vil alltid utgjøre dets primære fortolkningsnøkkel; derfor er kroppen noe som primært er, og ikke noe mennesket har, hevder han. All erkjennelse går via vår kroppslige tilstedeværelse i verden.

En som har sett nærmere på en slik dypere kroppstilnærming i vår tid, er trosviter Siv Ellen Kraft (2005), som beskriver ulike typer av kroppsmodifikasjoner, alt fra piercing til krokhenging. Hun forklarer at noen av disse nye kroppspraksisene gjenspeiler vår estetisering av kroppen, men samtidig er det en kultur som bruker kroppen for å oppnå en dypere erkjennelse av tilværelsen. Hun viser til et mangfold av senmoderne kroppsdyrkere som bruker kroppen som display for skjønnheten og som instrument for en religiøs dyrkelse. En viktig del av den dype kroppsopplevelsen er smertefornemmelse, skriver hun. For noen fungerer en slik selvpåført smerte som en renselsesprosess, en kroppsekstase (øvelse) som kan minne om oldtidens platonske og kristne kroppsaskese, men med motsatte intensjoner siden datidens kroppsaskese i større grad søkte å frigjøre seg fra kroppens materie, mens den postmoderne kroppsaskese søker en gjenforening med denne. I møte med den moderne overfladiske kroppskulturen søker man tilbake til en sanselig og helhetlig kroppserfaring.

Kraft viser også til etableringen av den globale landsby som muliggjør en eksperimentering med ulike kulturelle kroppstegn, tegn som paradoksalt nok speiler vår overfladiske kroppskultur, samtidig som den uttrykker en dypere lengsel etter en substansiell kroppserfaring. Hun kaller denne nye kroppspraksis for en ritualisert kroppskultur som søker tilbake til en førkristen kroppsorientering, samtidig som den trekker veksler på moder- 
nitetens innslag av eksperimentering, individualisme og nyreligiøsitet.

\section{St. Ireneus'og Moltmanns' kristne kroppskonsept}

Vår teologihistorie kan vise til mange eksempler hvor kroppen er blitt oppfattet som en negativ og adskilt størrelse. Som regel har man da sett på kroppen i lys av dens forgjengelige og syndige karakter. Samtidig kan teologihistorien vise til en mer positiv og helhetlig kroppstilnærming. Ireneus av Lyon (125 - 203 e.Kr.) og hans hovedverk Adversus Haereses (1999) er et eksempel på dette. Selve grunnlaget for å kunne hevde et positivt kroppssyn, finner han i det kristne dogme om inkarnasjonen. For Ireneus er det en avgjørende kontinuitet mellom Gud som skaper av det kroppslige mennesket og hans soningsverk (ibid.:5,2,1). Han er tydelig på at Jesu oppstandelse var en real-stofflig oppstandelse. Det var anstøtelig å tro på en kroppslig oppstandelse og evighet både i den greske og romerske kulturkrets, men for Ireneus ble troen på Guds allmakt truet dersom Gud ikke kunne reise kroppen opp fra graven og gi den nytt og evig liv (ibid.:5,3,2).

Mennesket er bare et fullverdig menneske så lenge det besitter sin sjel, sin ånd og sitt legeme, hevder Ireneus videre, tre enheter som kan frelses og inngå i en fullkommen, uløselig enhet. Her taler Ireneus om det «trikotome» (tredelte) menneske som samtidig inngår i en enhetlig størrelse. Han poengterer videre at legemligheten blir levendegjort i det den får sjel; i betydning Guds livspust i seg (ibid.: 1999:5,2). Her viser han til Genesis 2:7: «Og Herren Gud formet mannen av jord fra marken og blåste livspust inn i hans nese, så mannen ble til en levende skapning». Det hebraiske «nefesj» kan oversettes med livspust eller åndedrett, og blir nettopp knyttet til menneskets fysiske liv. Det gamle testamentet (GT) viser mange eksempler på at man i den hebraiske kulturen tenkte svært konkret og fysisk om sitt gudsforhold, der kroppsmetaforer blir tatt i bruk for å illustrere dette forholdet (Stordalen 1994).

I GT fremstår guddommen som den skapende håndverker som former legemet, $i$ motsetning til gnostikernes laverestående demiurg. ${ }^{7}$ Ireneus er tydelig på at den opprinnelige skaperakt viser at menneskekroppen fikk del i Guds kraft og visdom, og at den derfor ikke står i noe motsetningsforhold til det sjelelige i mennesket, slik kropp/sjeldualismen forfekter. Han polemiserer derfor mot den gnostiske dualisme og hevder at det er hele mennesket som er bærer av et «imago Dei», og ikke bare dets spirituelle del (Ireneus 1999:5,6,1). Det er hjertet som er menneskets sentrum i den hebraiske kulturkrets, i motsetning til den greske forestilling hvor sentrum ble lokalisert til hjernen og fornuften. Vi sier gjerne at det er det hjertet er fylt med, som speiler våre liv og identitet. Med andre ord, vi anvender hjerte som metafor og sete for våre følelser, tanker og handlinger.

Ireneus sitt helhetlige menneskesyn er også i tråd med Paulus sin tale om kjødet, i betydningen at hele mennesket («totus homo») synder, både dets sjel og legeme. ${ }^{8}$ Da blir kjød knyttet til det som er fordervet av syndens og dødens lov. Betegnelsen «kjød» finnes også i betydningen «hele mennes-

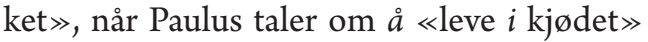
(Gal 2:20), som kan oversettes med: «å leve med kropp og sanser», til forskjell fra det $a$ «leve etter kjødet», som betyr: «å beher-

7 jf Gud formet (Gen 2:7 og 2:19), et ord som på hebraisk henspiller på håndverkeren som former med hendene. $8 \ll$ Sarx , gresk for «kjød», kan bety «kjøtt» og «vår jordiske bolig». 
skes av den kjødelige natur» (Rom 8:13). ${ }^{9}$ Når Guds Ånd tar bolig i mennesket, blir hele personen, også den psykiske siden, åndelig levendegjort. Ireneus gir her tydelig en nyansert fremstilling av kroppen, en kropp som går til grunne i sin nåværende stofflige form, men som i et kristologisk, soteriologisk og eskatologisk perspektiv blir en kroppsmaterie knyttet til uforgjengeligheten og hele mennesket (Ireneus 1999:5,8,2).

En som i moderne tid har tolket kroppen i lys av en positiv, kristen skapelsesteologi, er teologen Jürgen Moltmann (1926 -). Ifølge Stormark (2008) ønsker Moltmann å ta et oppgjør med vår kropp/sjel-dualistiske arv og fremmer en antropologi hvor mennesket består av enheten kropp, sjel og ånd. Han tar et oppgjør med både oldtidens greske og nytidens kartesianske forståelse av sjel og fornuft som overordnete, adskilte størrelser til kroppen (ibid.:110). Moltmann deler her Merleau-Ponty's tese om at kroppen er noe mennesket er, og tilføyer at denne må likestilles med sjelen som også er noe mennesket er, og viser til den jahvistiske skapelsesberetning spesielt, og GT generelt, hvor mennesket ikke blir splittet i størrelsene kropp, sjel og ånd, men utgjør et integrert hele som handlende enkeltmennesker. Ifølge Stormark vil Merleau-Ponty og Moltmann begrunne sin tese fundamentalt ulikt, idet Merleau-Ponty hevder bevisstheten blir en frukt av kroppens handling i tid og rom, mens Moltmann tolker bevisstheten, eller ånd, som en absolutt integrert del av kroppen selv, hvor kroppsmaterien er åndsfylt i seg selv, som uttrykk for Guds iboende ånd, se Stormark (2008:84). Moltmann viser også til den hebraiske tenkning som kategoriserer mennesket i dets livsrelasjoner og ikke gjennom abstraksjoner (ibid.:112).
Menneskets gudsbildelikhet må derfor, hevder Moltmann, forstås i relasjon til hele menneskets eksistens, ikke minst dets kroppslige væren. Han kaller derfor mennesket for en levende kroppslig åndsskikkelse (ibid.:113). I sin forståelse av menneskets imago Dei tar han også et oppgjør med Augustin, som knytter gudsbildelikheten først og fremst til menneskets sjel, forstått som en kroppsbeherskende, kjønnsløs sjel. En slik forståelse fører til at: «en fortrenger at kroppen er skapt i Guds bilde og dermed fortrenger en kroppens verdighet» (ibid.:71). Stormark tilføyer at (ibid.:69f.): «Analogien til Gud gjelder også menneskets kroppslige side. Hele mennesket - med kropp, ånd og sjel - er skapt i analogi til Gud [...] Vesentlig er også at denne står i den menneskeblevne, inkarnerte Guds sønns bilde (jf. Imago Christi) og venter på oppvekkelsen og en eskatologisk forherligelse på en ny jord i den framtidige verden $\gg$.

Moltmann er som nevnt en av dem som ønsker å ta et oppgjør med den tradisjonelle kropp/sjel-dualismen. Dette gjør han ved å løfte fram en sanselig, integrert og helhetlig kroppsidentitet, sett i lys av de radikale kristne dogmene om inkarnasjonen, om legemets oppstandelse og troen på et evig kroppslig liv. På denne måten minner hans kroppsforståelse om Ireneus' forståelse, selv om han nyanserer denne og setter den inn $\mathrm{i}$ en moderne språkdrakt. Det vil ikke i denne artikkelen være rom for å gi noen dypere fremstilling av Moltmann's skapelsesteologi. I korte trekk kan det hevdes at han forfekter en skapelsesberetning innenfor en messiansk og eskatologisk forståelseshorisont, der skapelsen sees i lys av disse. Slik skiller han seg fra en tradisjonell historisk, jødisk eksegese, uten at han dermed utelukker skapelsens historisitet. Hovedintensjonen er å vise til en

9 jf. det greske «psyché», som kan oversettes med både sjel og liv, eller livspust (Luk 12:20). 
teologi som foretar et brudd med den dualistiske antropologiske arv. Det nye testamentet sin kroppskultur og kroppsforståelse er selvsagt mangfoldig, fordi den viser kroppen sett fra ulike synsvinkler og tradisjoner; kroppsfremstillinger som lever i spenningsfeltet mellom en jødisk helhetlig og gresk «dualistisk» tenkning.

Også andre har vektlagt bibelens helhetlige antropologi-tenkning, der både et dikotomisk (kropp og psyke) og trikotomisk (kropp, psyke og sjel) menneske trer frem, ikke som motsetninger, men som supplerende størrelser innenfor rammen av en helhetlig antropologi (Erickson 2001; Kvalbein 1970). Kristendommen viser slik til en kropp som er underlagt både velsignelsen og forbannelsens lov på samme tid. En gudskapt kropp som forfaller, men som også er bærer av en dypere og positiv sanselighet og frodighet. Og en kropp som peker framover mot sin nyskapelse og et evig materielt liv.

\section{Et kristent danningsorientert} menneskesyn - verdi uavhengig av kroppsfasong og kroppsprestasjon

Hva betyr så denne eksplisitte kristne skapelsesteologien i forhold til dagens moderne kroppstilnærming? For det første innebærer menneskets gudsbildelikhet at vi er ukrenkelige i Guds øyne. Det bunner i et kristent menneskesyn om at ethvert menneske har en egenverdi uavhengig av prestasjon eller kroppsutseende. I lys av den kristne forestilling om menneskets forgjengelighet innebærer det at mennesket må akseptere sin status som et «døende/dødelig» vesen. Det innebærer at mennesket ikke kan klamre seg til troen på «evig ungdom», enten dette uttrykkes i form av troen på illusoriske kroppsidealer eller urealistiske kroppsprestasjoner. Det skulle bety at mennesket må akseptere at kropp og psyke er noe som gradvis eldes og svekkes, uten at denne fysiske aldringsprosessen dermed skal oppfattes som noe mindreverdig. Det innebærer også at mennesket i større grad må «gi rom for» og akseptere den handicappede, syke og gamle kroppen. Et kristent menneskesyn innebærer også en trøst og tro på at den forgjengelige kroppen en dag skal «reise seg» og bli frisk og vital.

Forestillingen om menneskets «imago Dei» innebærer også forestillingen om at mennesket er Guds medskapere eller hans medforvaltere (Gen 1:28). Implisitt i dette menes at Gud også står som skaper og opprettholder av menneskets daglige virke (Acta 14:15-17). En slik forløpende livsskapelse og livsopprettholdelse er samlet i betegnelsen creatio continua. Konstali overfører denne skapertanken på idretten og skriver (1979:80):

... i skapertanken forstått som creatio continua lå at Gud sørget for menneskets psykofysiske eksistens, men at Han til dette tar $i$ bruk menneskelig medaktivitet. Anvendt på idretten vil dette si at den enkelte ved å drive idrett og slik øke den fysiske og psykiske kapasitet, tar del $i$ Guds skapergjerning med seg selv her og nå. Den menneskelige organisme er stadig utsatt for «dødskrefter» som både kommer innenfra og utenfra. Den menneskelige kropp er en organisme som må trenes eller brukes for at den ikke skal degenereres.

Han skriver videre at etter bibelsk og reformatorisk syn finnes det en orden i skaperverket. Hos Luther ble de mange stender og ordninger sett på som redskaper for Guds fortsatte skapelse. Paulus taler også om øvrigheten som bildet på en slik ordning (Rom 13). Forvalteransvaret er her tenkt lagt til det offentlige, som skal sikre og skape gode menneskelige livsforhold i verden, og på den måten være et redskap for nestekjærligheten. 
Forestillingen er at Gud bruker sosiale relasjoner og institusjoner som redskap for sin fortsatte skapelse og opprettholdelse av verden. Det inkluderer også, ifølge Konstali, den organiserte idretten, som har fått et ansvarsmandat overfor befolkningen til å fremme idrettsglede og sunne kropper og sjeler. I et slikt skaperperspektiv blir idrettsutøvelse sett på som en del av vårt forvalteransvar (Austad 2004), en oppgave også toppidrettsutøvere kan se på som en virksomhet «til Guds ære» (Skjeldal 1995). Det skulle bety at kropp og bevegelse ikke kan reduseres til ren fasong eller effektivitetslogikk.

\section{OPPSUMMERING}

I drøftelsen av dagens kroppssyn betones det at vi fortsatt lever innenfor paradigmet kropp/sjel-dualisme. En antropologisk dualisme som hevdes er blitt forsterket i vår tid, med en utbredt idealisert kroppsdyrkelse - en svært sårbar situasjon når det samtidig er stadig flere som blir inaktive og fete. Det er også blitt påpekt at det finnes moderne, religiøse kroppsdyrkere som tydelig uttrykker en reaksjon mot en slik sekulær, overfladisk kroppstilnærming. Det er også blitt pekt på at denne kropp-sjel/dualismen har røtter blant annet i antikk og gnostisk tenkning, samt kristen teologihistorie, der kroppsmaterien er blitt sett på som noe negativt, til fordel for den sjelelige og ekstatiske kroppen. Bildet er ytterligere nyansert ved at det også er vist til kristne tenkere som fremmer en «kroppsrealisme» og «kroppsoptimisme», og et helhetlig syn på mennesket, der Gud står som skaper. Dette er en tenkning som er blitt underbygget med Bibel-referanser som både taler om kroppens immanens som uttrykk for den syndige, forgjengelige kroppen - og kroppens transcendens, som henspiller på den fremtidige evige kroppen. Dette er bibelske fremstillinger som ikke kan oppfattes som motsetninger, men heller som komplementære størrelser.

Jeg vil hevde at en slik kristen kroppsforståelse kan fungere i kontrast til vår tids strenge kroppsidealisering. En kroppsrealisme som tar høyde for kroppens forgjengelighet, og samtidig en kroppsoptimisme som taler om kroppens evige fysiske nyskapelse fjernt fra den moderne illusoriske og maskinelle kroppsforestilling. Kristen kroppsoptimisme handler også om å plassere kroppen innenfor en større danningskontekst der kroppskultur ikke ensidig handler om kroppsfasong og kroppsprestasjoner, men også er knyttet til andre kvaliteter som omhandler det sosialetiske, helsemessige og kanskje mest av alt: kroppsbevegelsen og kroppsopplevelsen i seg selv. Er det noe vår tid sårt trenger, så tror jeg det må være å løfte frem den reale, sanselige kroppen slik denne kommer til uttrykk. Gjennom en bevisstgjøring av denne, vil det også bli mulig å konstruere positive og realistiske kroppsbilder, noe som blir særs viktig i en tid hvor avstanden synes å bare bli større mellom den fete, aldrende, syke kroppen og de illusoriske kroppsidealene.

\section{REFERANSER}

Augustin, Aurelius. 1961. Bekjennelser: Bok I-X. Oslo: Aschehoug i samarbeid med Fondet for Thorleif Dahls kulturbibliotek og Det norske akademi for sprog og litteratur.

Augustinus, Aurelius. 1884. Om Guds stat. Vol.

8, Christiania: Malling.

Austad, Torleiv. 2004. «I bevegelse - til fornyelse. Kristent syn på idrett». I Tidsskrift for Religion og kultur 6, side 75-82.

Baudrillard, Jean. 1994. Simulacra and Simulation. Ann Arbor, Mich.: University of Michigan Press. 
Baudrillard, Jean. 1998. The consumer society: myths and structures. London: Sage.

Bauman, Zygmunt. 2001. Flytende modernitet. Oslo: Vidarforlaget.

Breivik, Gunnar. 2013. Jakten på et bedre liv: Fysisk aktivitet $i$ den norske befolkning 19852011. Oslo: Universitetsforlaget.

Descartes, René. 1992. Meditasjoner over filosofiens grunnlag og andre tekster. Oslo: Aschehoug i samarbeid med Fondet for Thorleif Dahls kulturbibliotek og Det norske akademi for sprog og litteratur.

Dombrowski, Daniel A. 2009. Contemporary Athletics and Ancient Greek Ideals. Chicago: University of Chicago Press.

Eichberg, Henning. 1986. «Den sanselige i at korsfæstede kødet. Om idret, krop og katolisisme.» I Religion og sport, red. E. Jespersen, side 68-81. Slagelse: Bavnebanke.

Erickson, Millard J. 2001. Christian Theology. Grand Rapids, Mich. Baker Books.

Foucault, Michel. 1997. Overvåkning og straff: Det moderne fengsels historie. Oslo: Gyldendal.

Giddens, Anthony. 1997. Modernitetens konsekvenser. Oslo: Pax.

Goksøyr, Matti. 2008. Historien om norsk idrett. Oslo: Abstrakt forlag.

Guttmann, Allen. 1978. From Ritual to Record: The Nature of Modern Sports. New York: Columbia University Press.

Hyland, Drew A. (1990). Philosophy of sport. New York: Paragon House.

Irenaeus. 1999. Mot kjetterne. Frederiksberg: Anis.

Konstali, Kjell. 1979. Idrett og etikk: en drøfting av idrettens verdigrunnlag ilys av kristen etikk. Oslo: Menighetsfakultetet.

Korsgaard, Ove. 1986. «Sport som religiøs praksis.» I Religion og sport, red. E. Jespersen, side 57-67. Slagelse: Bavnebanke.
Kraft, Siv-Ellen. 2005. Den ville kroppen: tatovering, piercing og smerteritualer i dag. Oslo: Pax.

Kvalbein, Hans. 1970. «Eskatologi og antropologi hos Paulus $\gg$. I Tidsskrift for teologi og kirke, side 203-14.

Ladd, Tony og James A. Mathisen. 1999. Muscular Christianity: Evangelical Protestants and the Development of American Sport. Grand Rapids: Baker.

Lasch, Christopher. 1978. Den narsissistiske kultur. Oslo: Pax.

Leder, Drew. 1990. The Absent Body. Chicago: University of Chicago Press.

Lippe, Gerd von der. 2011. «Medierte idrettsidoler - fra rollemodeller til modeller? $\gg$ I Norsk Idrett: Indre spenning og ytre press, red. D.V. Hanstad, side199-214. Oslo: Akilles.

Loland, Sigmund. 2003. «Kroppssyn, idrett og mosjon». I Tidsskrift for den norske legeforening. [online] tilgjengelig: http://tidsskriftet.no/article/190405. [2. april 2005].

Martinsen, Egil W. 2011. Kropp og sinn. Fysisk aktivitet - psykisk helse - kognitiv terapi. Bergen: Fagbokforlaget.

McLuhan, Marshall. 1997. Mennesket og media. Oslo: Pax.

Merleau-Ponty, Maurice. 1994. Kroppens fenomenologi. Oslo: Pax.

Miller, Stephen G. 2004. Ancient Greek Athletics. New Haven, Conn.: Yale University Press.

Morris, Desmond. 1998. Mann og kvinne: Seksualitetens forunderlige historie. Oslo: Cappelen.

NIF. 2011. Norges idrettsforbund og den olympiske komités lov. [online] tilgjengelig: http://www.lovdata.no/nif/nifloven.html [11. Juni 2015].

Platon. 2001. Samlede Verker Bind IV, Faidon, Symposiet, Faidros. Oslo: Vidarforlagets kulturbibliotek. 
Postman, Neil. 2004. Vi morer oss til døde. Oslo: De norske bokklubbene.

Putney, Clifford. 2001. Muscular Christianity:

Manhood and Sports in Protestant America, 1880-1920. Cambridge, Mass.: Harvard University Press.

Reid, Heather Lynne. 2011. Athletics and Philosophy in the Ancient World: Contests of Virtue. London: Routledge.

Rødje, Kjetil og Berit Grøholt. 2004. Helseprofil for barn og ungdom i Akershus: Barnerapport. Vol. nr 1-2004, Oslo: Kunnskapssenteret.

Skjeldal, Gudmund. 1995. På villspor: Takk og farvel til toppidretten. Oslo: Forum: Aschehoug.

Skårderud, Finn. 1991. Sultekunstnerne: Kultur, kropp og kontroll. Oslo: Aschehoug.

Skårderud, Finn. 1998. Uro: En reise $i$ det moderne selvet. Oslo: Aschehoug.

Spicker, Stuart F. 1970. The Philosophy of the Body: Rejections of Cartesian Dualism. Chicago: Quadrangle Books.

Stordalen, Terje. 1994. Støv og livspust: Mennesket i Det gamle testamente. Oslo: Universitetsforlaget.

Stormark, Jarle. 2008. Kropp og identitet, og håpet om nyskapelse: En skapelsesteologisk undersøkelse av betydningen av kropp og identitet $i$ troen $p a ̊$ «legemets oppstandelse» hos Jürgen Moltmann i Systematische Beiträge Zur Theologie. Vol. no. 24, Oslo: Unipub.

Sundgot-Borgen, Jorunn, Monica Klungland Torstveit og Finn Skårderud. 2004. «Spiseforstyrrelser i idretten». side 212629. I Tidsskrift for den norske legeforening.
Synnott, Anthony. 1993. The Body Social: Symbolism, Self and Society. London: Routledge.

Sæle, Ove Olsen. 2010. Helt eller delt menneske. Et basketak med vår vestlige kropp/sjel-dualisme. Bergen: NLA-forlaget.

Sæle, Ove Olsen. 2012. "Fair play i barnehagen. Et viktig bidrag i barns sosial-etiske danning”. Barn(3), 23-38.

Sæle, Ove Olsen. 2013. "Paidia og paideia barns lek og danning i lys av aristotelisk dydsetikk". Prismet, 64(1), 19-30.

Sæle, Ove Olsen. 2014. «Den luksuriøse kroppen - En kritisk drøftelse av Jean Baudrillard's kroppskonsept i lys av hans postmoderne tenkning om hyperrealitet». Theofilos. Vol.6, nr.3., 421-435.

Tangen, Jan Ove. 2003. "Citius - Altius Fortius: Idrettens patologiske trosartikkel”. I I Bevegelse: Et festskrift til Gunnar Breivik på hans 60-årsdag, red. Vegard Fusche Moe og Gunnar Breivik, side 103-19. Oslo: Gyldendal undervisning.

Thorbjørnsen, Svein Olaf. 2011. En plass på pallen: konkurransen, idretten og mennesket. Kristiansand: Høyskoleforlaget.

Turner, Bryan. 2008. The Body of Society: Explorations in Social Theory. London: Sage.

Weber, Max. 1973. Den protestantiske etikk og kapitalismens ånd. Oslo: Gyldendal.

Zoglowek, Herbert. 2006. «Kroppsøving = kroppsdannelse, hva ellers?» Kroppsøving. Vol. 56, nr.4., 12-16. 